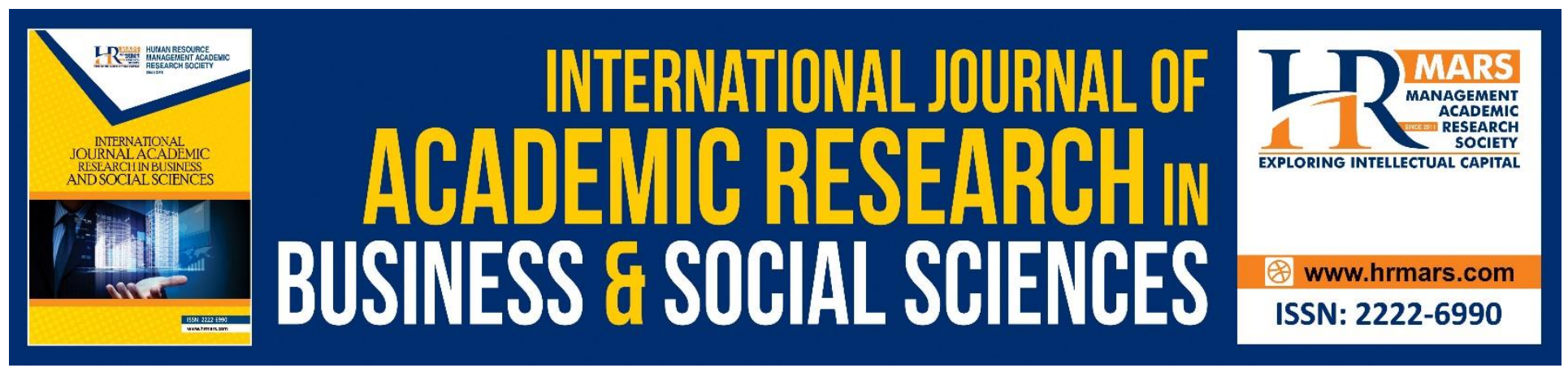

\title{
Development of Sustainability Framework Based On the Theory of Resource Based View
}

\author{
Maryam Pervez Khan, Dr. Noraini Abu Talib, Dr. Tan Owee Kowang
}

To Link this Article: http://dx.doi.org/10.6007/IJARBSS/v8-i7/4406 DOI: $10.6007 /$ IJARBSS/v8-i7/4406

Received: 13 June 2018, Revised: 29 June 2018, Accepted: 13 July 2018

Published Online: 28 July 2018

In-Text Citation: (Khan, Talib, \& Kowang, 2018)

To Cite this Article: Khan, M. P., Talib, N. A., \& Kowang, T. O. (2018). Development of Sustainability Framework Based On the Theory of Resource Based View. International Journal of Academic Research in Business and Social Sciences, 8(7), 636-647.

\section{Copyright: (c) 2018 The Author(s)}

Published by Human Resource Management Academic Research Society (www.hrmars.com)

This article is published under the Creative Commons Attribution (CC BY 4.0) license. Anyone may reproduce, distribute, translate and create derivative works of this article (for both commercial and non-commercial purposes), subject to full attribution to the original publication and authors. The full terms of this license may be seen

at: http://creativecommons.org/licences/by/4.0/legalcode

Vol. 8, No. 7, July 2018, Pg. 636 - 647

http://hrmars.com/index.php/pages/detail/IJARBSS

JOURNAL HOMEPAGE

Full Terms \& Conditions of access and use can be found at http://hrmars.com/index.php/pages/detail/publication-ethics 


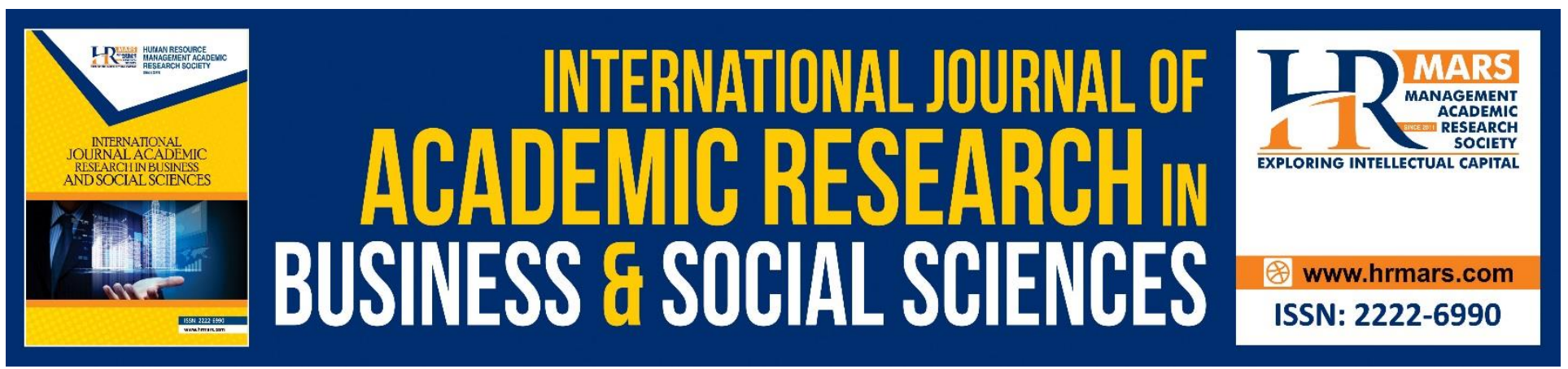

\title{
Development of Sustainability Framework Based On the Theory of Resource Based View
}

\author{
Maryam Pervez Khan, Dr. Noraini Abu Talib, Dr.Tan Owee Kowang \\ Azman Hashim International Business School, Universitie Teknologi Malaysia, Johor, Malaysia
}

\begin{abstract}
Lean, Green and Agile management are arguably among the most frequently discussed topics in the business-operations management literature. These three concepts are perfectly aligned with theory of resource based view, which advocates a symbiotic relationship between a firm resources and capabilities and performance. In spite of the theoretical and historical linkages between these concepts however, there has been minimal efforts at integrating the concepts of Lean, Green and Agile particularly with regard to sustainability performance. This study therefore proposes a conceptual framework to examine the impact of Lean, Green and Agile practices and the relationship between sustainability performances of a firm. The study is conceptual in nature, as it involves the review of existing literature critically and systematically and synthesis of existing studies and relevant theory have been discussed, leading to the formulation of the proposed framework. Documented evidence in the literature shows that these concepts are historically linked. In spite of the linkage, there have been minimal efforts at integrating the concept of Lean Green Agile to achieve sustainability performance of the firm. The proposed framework provides a guide for examining the impact of Lean Green and Agile practices and sustainability performance achievement. It is hoped that findings emanating from the study will aid companies to further understand the importance of Lean Green and Agile practices in their day to day performance.
\end{abstract}

Keywords: Lean, Green, Agile, Sustainability performance.

\section{Introduction}

In extremely business competitive environment manufacturers all over the world from different stakeholders facing pressures to hold sustainability management system. Zhu et al. (2013) Highlight that companies cannot fully meet and improve the expectations of different stakeholders such as competitors, consumers and government agencies while focusing alone on single bottom line approach. To achieve sustainability and survival of the firm, it is necessary to find ways to improve their performance concurrently in environmental, economic and social dimensions. Three of these performance indicators environmental, economic and social are stated as TBL triple bottom line. The best ways to measure sustainability performance of a firm is considered as 3BL.From different case studies it has been found that there is a correlation between combination of lean and green and high firm performance. The key path to pursue sustainability is the concurrent implementation of 
INTERNATIONAL JOURNAL OF ACADEMIC RESEARCH IN BUSINESS AND SOCIAL SCIENCES Vol. 8, No. 7, July 2018, E-ISSN: 2222-6990 @ 2018 HRMARS

practices of lean and green by firm. The performance outcome of the firm will be extremely more ideal as compared to the alone implementation of lean. It would be superior to involve certain green practices for the achievement of higher 3BL performance if a firm executing lean practices only. On sustainability, past research have focused on industrialized nation of west with less attention paid to developing economies.

As lean practice approach is an operations management which wishes to waste elimination in design, production, supply network, factory management (Chauhan et al., 2012).Its tools and methods, placement with green pattern all appears natural Garza-Reyes (2015).Therefore, practice of lean and green better understanding is required Zhan et al. (2018). Green and lean implementation link have been focused by (Bergmiller et al., 2009; Dües et al., 2013; Hajmohammad et al., 2013).Linkage between green and lean practices and supply chain performance have been analyzed by a segment of other authors. While some of them fixated on performance indicators of green and lean(Cabral et al., 2012(Govindan et al., 2015)).Green and lean practices harmonization guarantees the benefits for instance improvement of environment quality and process flow, reduction of lead time and cost, improved commitment and employee morale(EPA, 2007).Inconclusive and limited research is done on the collaboration between lean and green practices as well as performance of the organization. Garza-Reyes (2015) Called for more extensive and robust research to fill this gap. As the dynamics of business has changed now extremely due to fast transformation in market condition, technology, customer requirements and from local towards global field increased competition has seen from last two decades(Vazquez-Bustelo et al., 2007). This rapid globalization demands the need for openness through practicing Agile Manufacturing principles. AM executes manufacturing organization transformation to respond to vibrant market changes Aravind Raj et al. (2013). So the aim of this study is to expand the knowledge about the role of Lean Green and Agile practices and their effect on sustainability performance of the firm. As this study can be used as a basis to achieve the ultimate goal of sustainability.

\section{Literature Review}

\section{The Concept of Sustainability}

The word sustainability meaning can be constructed in many ways but the common interpretation which is used mostly is related to the development of humans on earth.Brundtland (1987) Originally defined the sustainable development concept on UN General Assembly behalf. Sustainable development need came into being as a response related to increasing concerns regarding economic growth connection with environmental damage (Factbook, 2008).Sustainable development is defined by the commission as a development which meets present needs without compromising future generations ability to encounter their own needs Brundtland (1987).Because of too much ambiguity original definition was heavily criticized. Numerous new definitions have been established over time built on different interpretations regarding sustainable development true meaning.

\section{Sustainability Performance}

As industrial performance metrics have been moving from economic centric performance measurement towards sustainability and sustainability performance. Elkington (1998) Suggested the term sustainability and is well defined as corporate viewpoint expansion which reflects economic, environmental and social aspects. Presently an increasing number of companies are following sustainability objectives by integrating in their business practices, for instance Green initiatives (Maxwell et al., 2006; Teixeira et al., 2012).Yet there are still studies lack which considers the 
INTERNATIONAL JOURNAL OF ACADEMIC RESEARCH IN BUSINESS AND SOCIAL SCIENCES Vol. 8, No. 7, July 2018, E-ISSN: 2222-6990 @ 2018 HRMARS

dimensions of triple bottom line (TBL) (i.e. economic, social and environmental) simultaneously. Elkington (1998), stated that to motivate companies on the way to sustainability performance, significant changes are required for the focus of companies regarding dimensions of triple bottom line. Therefore it is fundamental to get a thoughtfulness of how manufacturing practices effects the sustainability performance.

\section{Concept of Lean Manufacturing}

In production system the efficiency and quality improvement practices implemented by Toyota called as Toyota Production system, the concept of Lean has progressed as a thinking with slogan "to do more with less" and intentions waste eradication in industry every aspect while adding product value with continuous and organized methodology Pavnaskar et al. (2003).Other than equipment essential resources, workers, parts, time, space, machine, effort, which are essential to add product value. Seven categories waste recognized from TPS involve inventory, over processing, overproduction, transportation, waiting, defects and motion Hines et al. (1997).For waste elimination Lean manufacturing uses range of practices such as workplace housekeeping techniques, setup time reduction, value stream mapping (VSM), pull production system, just in time JIT, total productive maintenance TPM, statistical process control, continuous improvement, total quality management, cellular manufacturing(Eswaramoorthi et al., 2011).

As Principle goal is not to handle waste elimination but also to guarantee well organized and smooth flow production(Liker, 2004).Lean manufacturing has expanded and progressed over the time further than its origin in automotive industry(Womack, 1990).Lean practices successful implementation has described by different researchers in variability of industries which supports the fact it is a universal philosophy and its practices can be implemented in any industry to a sure amount Shah et al. (2003).

\section{Concept of Green Manufacturing}

In most general way Green Manufacturing is defined as "a manufacturing practice which do not harm environment during any of its journey phase". It includes product Green design, usage of raw material which is environmental friendly, packaging in an environmental friendly way, distribution, after product end life reuse. It lowers trash and slows depletion of natural resources (Foster, 2001). It stresses on reducing parts, material rationalizing, components reuse. It covers amount of manufacturing issues involving 6Rs (Jawahir et al., 2006) regulatory compliance, management of waste, conservation, protection of environment, control related to pollution and other joined requirements. To improve efficiency of organization via GM Practices there are abundant opportunities along with protection of environment influence financial gains(Roy et al., 2016).Harmonizing economic and environmental performance has established noteworthy for organizations fronting competitive, community and regulatory pressures Bai et al. (2015).

Numerous campaigns have taking place in different countries for the promotion of GM and are stressing on recycled material usage with energy consumption reduction Woo et al. (2016).Origination of GM notions is from Germany, its activities nature, scope and focus keep moving with reverence to time. It's not limited to manufacturing only. It has been evolving continuously one can notice and demanding comprehensive treatments.

\section{Green and Lean Fundamental Practices}

By studying the literature, the key practices to enhance organization performance are attitude and mindset, involvement of employees, management and leadership, empowerment and training, 
INTERNATIONAL JOURNAL OF ACADEMIC RESEARCH IN BUSINESS AND SOCIAL SCIENCES Vol. 8, No. 7, July 2018, E-ISSN: 2222-6990 @ 2018 HRMARS

integrated approach, tools techniques and technology, supplier relations training and development, customer relations. According to previous literature, all of the Lean Green practice are integrative. Firstly. People who operates Lean Green system there mind set and attitude are fundamental. As Green Lean practice is not about only to change things it's also about to change the thinking of people. Organizations should think flexible and small somewhat to think big. So that problems built opportunities for improvement rather dictating blame(Jeyaraman et al., 2010). Secondly strong committed leadership is fundamental to success. As the difference between failure and success of Green and Lean starts with leadership also backed by the literature (Rothenberg et al., 2001). Thirdly involvement of employees can assist in different ways in Lean Green practice with factors involving attitude, knowledge, experience, skills, adaptation, influence, customer awareness, to take initiative and to think and prioritize about enterprise (Florida, 1996; Unnikrishnan et al., 2007). Fourth Dües et al. (2013) stated clearly that Green Lean system effectiveness depends on integrated approach adoption. Hence Lean and Green should be comprehensive integrated management pattern, and a manufacturing philosophy which should be practiced consistently throughout an organization. As it get easy to see many benefits which can be achieved through Lean Green understanding tools techniques and their appropriate usage (Hines et al., 2004). Hence it should be considered as critical Lean Green practice in organization. Numerous studies have investigated and considered the effect of initiatives of lean green on organizational performance and their incorporation as combined single approach(Dües et al., 2013; Garza-Reyes, 2015; Kurdve et al., 2014; Larson et al., 2004; Mollenkopf et al., 2010; Pampanelli et al., 2014; Sobral et al., 2013). Therefore, despite these studies, research exploring lean green practice impact on performance of organization is still in their early stages. Particularly, no systematic study, has commenced to identify key lean green practices, which make the difference among failure and success in lean green implementation.

\section{Agile Manufacturing}

Comparatively, a new concept of business is Agile manufacturing (AM). (AM) being regarded as capable to meet unpredictable requirements of business with adaptability(Dove, 1994), as Kidd (1996) mentioned, it is described as a ability to manage and to respond unpredictable requirements. One of AM systems features is their robustness, meaning that they able to bear interruptions and alterations within given environment of requirements of demand. As AM focused towards planned strategic approach directed towards constant change. AM technology was first invented in 1991 at Leigh University as a program backed by the government to explore on global scale US manufacturing future. In AM adaptation occurs on regular basis so that companies counteract the influence which change exerts upon performance measures. Due to this time of change many companies focuses towards core competencies of them by evolving business applications. In AM, the change philosophy found consists of a mission to undertake the competition permanently, as the market evolves ruthlessly.Sharp et al. (1999) Pointed out that AM is a change philosophy so its key pillars are information technology (IT), intelligent workers and corporate partners. 


\section{Components of Agile Manufacturing}

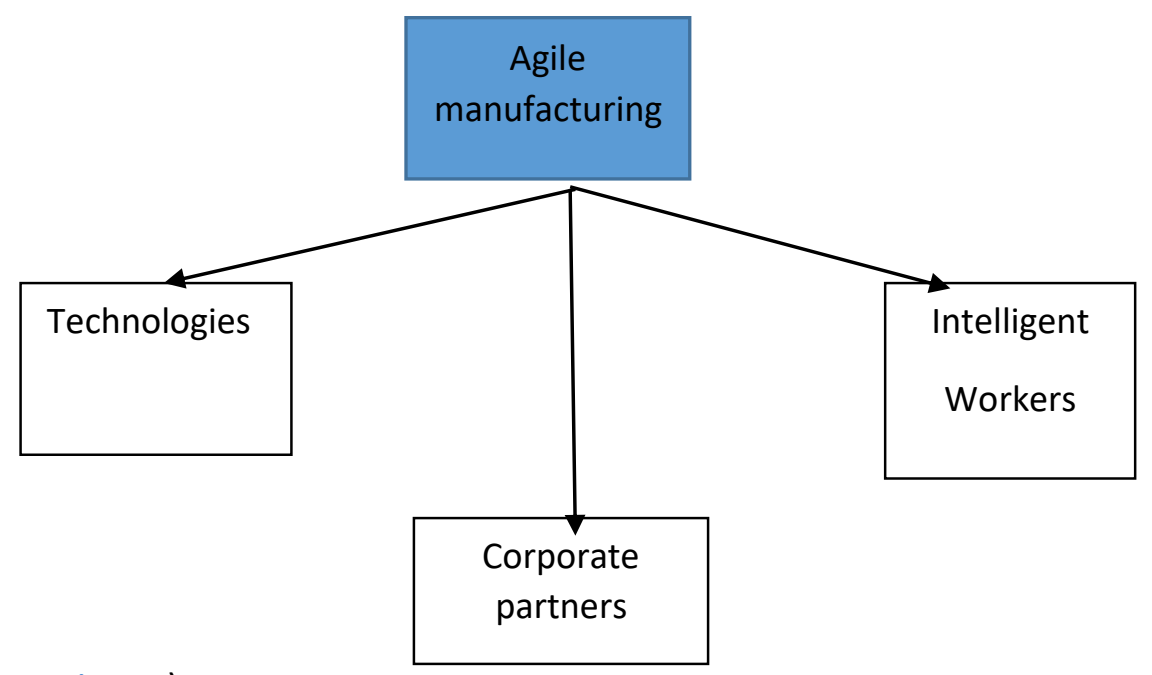

Fig1 Source (www.nait.org)

\section{People}

In the growth and development of organization, employee role is very much important. With knowledgeable workers help agile manufacturing can effectively operate. Attributes related to people observed are: flexible and multi skilled people, employee's empowerment, employee's involvement, employee satisfaction, team across company, continuous development and training, employee rewarding, personnel commitment, continuous man power motivation, on management employee trust(Gunasekaran, 1999; Sharifi et al., 1999; Sharp et al., 1999; Sherehiy et al., 2007)

\section{Technologies}

It enable people to share information efficiently and effectively with in the environment, agile manufacturing demands Technologies. Administrative function should be integrated with the advanced design manufacturing functions. To improve sensing dynamically(Elkins et al., 2004), technologies can help in unpredictability world when there is high uncertainty in demand and supply which enables firm to respond according to market needs with speed Gunasekaran (1998). Over last decade technologies have been evolved, use of electronic commerce, CNC, robotics, enterprise resource planning (ERP), cloud computing(Zhang et al., 2014), group technology lay out has redefined the concept of AM.

\section{Virtual enterprise integration}

Virtual corporate partners add value to product needed and are the contributors. Factors linked to virtual integration are; sharing infrastructure and as well as other assets, financial resources sharing, concepts sharing, R\&D sharing, with other companies data integration based upon computers, temporary alliances, quick formation of partnership, formation of multi and joint venture (Gunasekaran, 1999; Sharp et al., 1999). Entrance towards new markets get easy because of the fact that resources can be changed easily that's why virtual enterprise is valued. 
INTERNATIONAL JOURNAL OF ACADEMIC RESEARCH IN BUSINESS AND SOCIAL SCIENCES Vol. 8, No. 7, July 2018, E-ISSN: 2222-6990 @ 2018 HRMARS

\section{Resource based view Theory}

Firm resource based view (RBV) has been discussion subject in strategic management field among researchers. RBV suggests that success of the firm depends upon the capabilities and resources which have certain characteristics Galbreath (2005). A firm capabilities and resources can be distinct as including all capabilities, assets, organizational processes, firm knowledge and attributes control by firm which allows firm to grow and available factors bundle possessed and controlled by firm and can be used for building up and implementing their strategies(Amit et al., 1993). Sustainable competitive advantage can be generated through firm capabilities and resources when following characteristics they have, non-substitutability, rarity, value, inimitability (J. Barney, 1991).Later J. B. Barney (1995),focused sustained implementation of those strategies which can improve their effectiveness and efficiency. This is competitive advantage need, unique capabilities and resources which firm could bring towards its environment and competition.

Business managers and owners must discover these capabilities and resources by looking inside firm for those resources which are rare, valuable and imperfectly imitable and then achieve these resources. Resources right combination is compulsory to accomplish sustainable competitive advantage(Ulrich et al., 1995).

Independently, Lean Green practices, can be measured as imitable assets, homogenous attained by industrial opponents, and it may bound organization ability to attain competitive advantage when applied in separation(Enz, 2008). It has been stated that sustainable competitive advantage can never be obtained through one resource. Bundling resources in an innovative way, organization should think about which may get difficult for competitors to imitate. In Lean Green practices context, integrated Lean Green practice synergistic effect can generate heterogeneity, superior value and innovation through production, design, and delivery process performance can be improved(Colicchia et al., 2017; Garza-Reyes, 2015; Yang et al., 2011). Different organization resources for instance, Lean Green when applied simultaneously enhances the resources complexity which competitors will try to imitate, synergistic application of them would drive innovation and will deliver increased performance as compared to each of them if executed in separation(Cherrafi et al., 2017; GarzaReyes, 2015; Khanchanapong et al., 2014). (Cua et al., 2001; Ketokivi et al., 2004) Further supported the argument advising organizations to create basic manufacturing practices different configurations to improve capabilities specific aspects to motivate and achieve competitive advantage. Different manufacturing strategies joined up and integrated approaches including Green Lean practices to innovate creative products and processes can help organization which competitors would find hard to copy (Baines et al., 2012; Figge et al., 2012; Sarkis, 2001) Similarly Agile manufacturing based upon those key capabilities which are important to survive for continuously changing and turbulent environment. Agility key characteristic is flexibility(Christopher et al., 2001). Flexibility contains agility(Narasimhan et al., 2006). As difference between agility and flexibility does exist. From resource based view one difference comes which suggests core competencies of firm lies in organizational inimitable or coordinative capabilities(Teece, 1986; Wernerfelt, 1984). By tapping synergies agility is achieved between flexibility different forms within firms(Agarwal et al., 2006). Therefore, from perspective of resource based agility is a fundamental competence which based upon various capabilities specially flexibility different forms to attain sustainable competitive advantage and firm superior performance. 


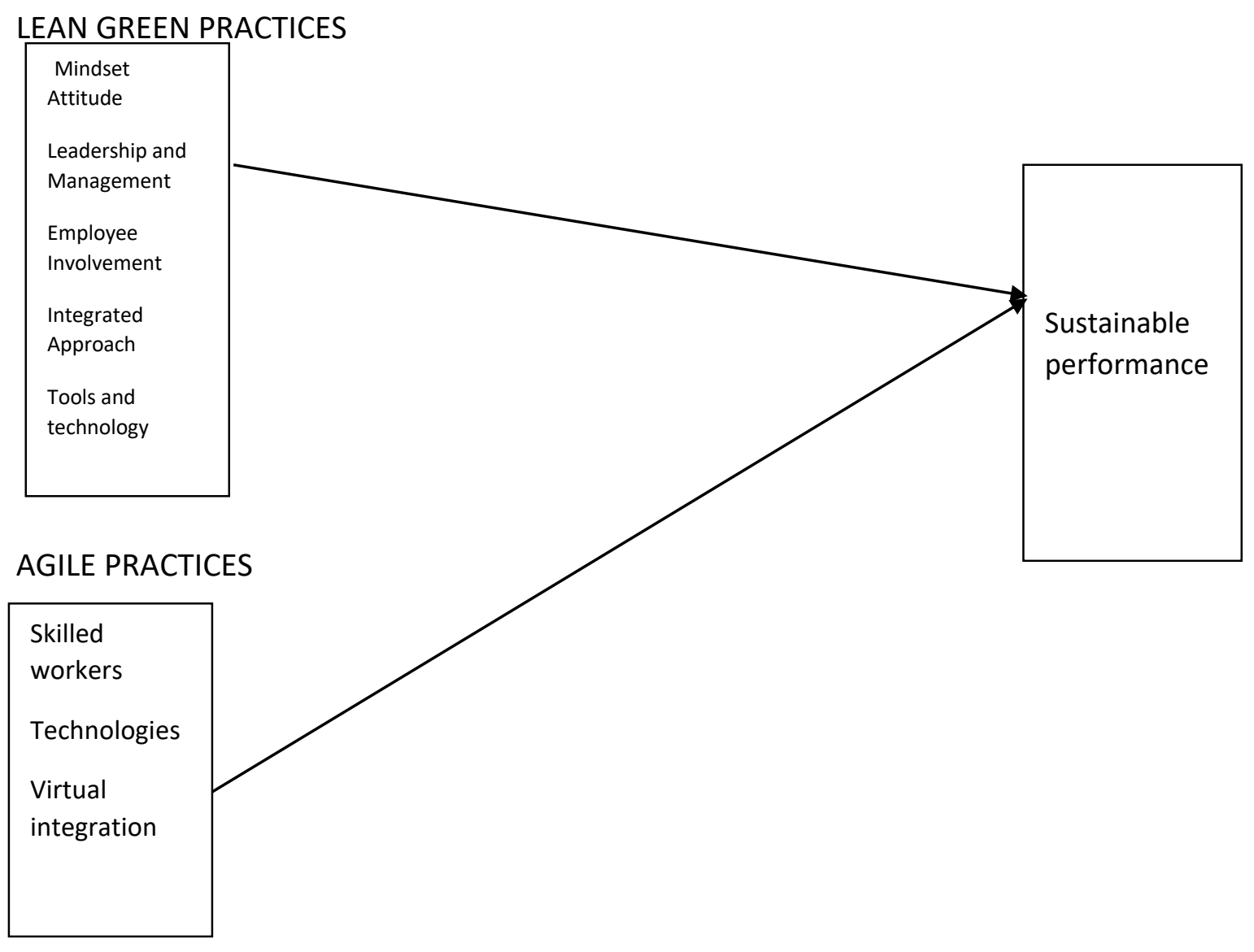

Figure 2: Proposed Framework

\section{Discussion}

In above figure 2 a framework has been proposed which incorporates the Lean Green and Agile key practices in an easy and simple manner. It is obvious from the literature that lean green and agile can bring improvement in lead time production, value added time, speed, trust between employees and management, brings customer value and partners which are critical for the successful growth and for firm sustainable performance.

\section{Conclusion and Future Research}

As three dimensional issue, in broader manner, sustainability should be studied Abdul-Rashid et al. (2017).To bridge the gap, Lean Green and Agile manufacturing concepts have been integrated attempting to build sustainability comprehensive framework for future test.

\section{Acknowledgement}

The authors would like to thank Ministry of Higher Education and Universiti Teknologi Malaysia, for providing financial support $18 \mathrm{H} 59$ to publish this paper. 
INTERNATIONAL JOURNAL OF ACADEMIC RESEARCH IN BUSINESS AND SOCIAL SCIENCES Vol. 8, No. 7, July 2018, E-ISSN: 2222-6990 @ 2018 HRMARS

\section{Corresponding Author}

Dr. Noraini AbuTalib, Email; m-aini@utm.my, Azman Hashim International Business School, Universiti Teknologi, Malaysia.

\section{References}

Abdul-Rashid, S. H., Sakundarini, N., Raja Ghazilla, R. A., \& Thurasamy, R. (2017). The impact of sustainable manufacturing practices on sustainability performance: empirical evidence from Malaysia. International Journal of Operations \& Production Management, 37(2), 182-204.

Agarwal, A., Shankar, R., \& Tiwari, M. (2006). Modeling the metrics of lean, agile and leagile supply chain: An ANP-based approach. European Journal of Operational Research, 173(1), 211-225.

Amit, R., \& Schoemaker, P. J. (1993). Strategic assets and organizational rent. Strategic management journal, 14(1), 33-46.

Aravind Raj, S., Sudheer, A., Vinodh, S., \& Anand, G. (2013). A mathematical model to evaluate the role of agility enablers and criteria in a manufacturing environment. International Journal of Production Research, 51(19), 5971-5984.

Bai, C., Sarkis, J., \& Dou, Y. (2015). Corporate sustainability development in China: review and analysis. Industrial Management \& Data Systems, 115(1), 5-40.

Baines, T., Brown, S., Benedettini, O., \& Ball, P. (2012). Examining green production and its role within the competitive strategy of manufacturers. Journal of Industrial Engineering and Management, 5(1), 53.

Barney, J. (1991). Firm resources and sustained competitive advantage. Journal of management, 17(1), 99-120.

Barney, J. B. (1995). Looking inside for competitive advantage. The Academy of Management Executive, 9(4), 49-61.

Bergmiller, G. G., \& McCright, P. R. (2009). Parallel models for lean and green operations. Paper presented at the Proceedings of the 2009 industrial engineering research conference.

Brundtland, G. H. (1987). Sustainable development. Towards Sustainable Development. The Panos Institute, London. Pages viii- $x$.

Chauhan, G., \& Singh, T. (2012). Measuring parameters of lean manufacturing realization. Measuring Business Excellence, 16(3), 57-71.

Cherrafi, A., Elfezazi, S., Govindan, K., Garza-Reyes, J. A., Benhida, K., \& Mokhlis, A. (2017). A framework for the integration of Green and Lean Six Sigma for superior sustainability performance. International Journal of Production Research, 55(15), 4481-4515.

Christopher, M., \& Towill, D. (2001). An integrated model for the design of agile supply chains. International Journal of Physical Distribution \& Logistics Management, 31(4), 235-246.

Colicchia, C., Creazza, A., \& Dallari, F. (2017). Lean and green supply chain management through intermodal transport: insights from the fast moving consumer goods industry. Production Planning \& Control, 28(4), 321-334.

Cua, K. O., McKone, K. E., \& Schroeder, R. G. (2001). Relationships between implementation of TQM, JIT, and TPM and manufacturing performance. Journal of operations management, 19(6), 675694.

Dove, R. (1994). Tools for analyzing and constructing agility. Paper presented at the Proceedings of the Third Annual Agility Forum Conference/Workshop, Austin, TX. 
INTERNATIONAL JOURNAL OF ACADEMIC RESEARCH IN BUSINESS AND SOCIAL SCIENCES

Vol. 8, No. 7, July 2018, E-ISSN: 2222-6990 @ 2018 HRMARS

Dües, C. M., Tan, K. H., \& Lim, M. (2013). Green as the new Lean: how to use Lean practices as a catalyst to greening your supply chain. Journal of Cleaner Production, 40, 93-100.

Elkington, J. (1998). Partnerships from cannibals with forks: The triple bottom line of 21st-century business. Environmental Quality Management, 8(1), 37-51.

Elkins, D. A., Huang, N., \& Alden, J. M. (2004). Agile manufacturing systems in the automotive industry. International Journal of Production Economics, 91(3), 201-214.

Enz, C. A. (2008). Creating a competitive advantage by building resource capability: The case of Outback Steakhouse Korea. Cornell Hospitality Quarterly, 49(1), 73-78.

Eswaramoorthi, M., Kathiresan, G., Prasad, P., \& Mohanram, P. (2011). A survey on lean practices in Indian machine tool industries. The International Journal of Advanced Manufacturing Technology, 52(9-12), 1091-1101.

Factbook, O. (2008). OECD Factbook 2008: Economic, Environmental and Social Statistics: OeCD.

Figge, F., \& Hahn, T. (2012). Is green and profitable sustainable? Assessing the trade-off between economic and environmental aspects. International Journal of Production Economics, 140(1), 92-102.

Florida, R. (1996). Lean and green: the move to environmentally conscious manufacturing. California management review, 39(1), 80-105.

Foster, S. T. (2001). Managing quality: an integrative approach (Vol. 223): Prentice Hall Upper Saddle River.

Galbreath, J. (2005). Which resources matter the most to firm success? An exploratory study of resource-based theory. Technovation, 25(9), 979-987.

Garza-Reyes, J. A. (2015). Lean and green-a systematic review of the state of the art literature. Journal of Cleaner Production, 102, 18-29.

Govindan, K., Diabat, A., \& Shankar, K. M. (2015). Analyzing the drivers of green manufacturing with fuzzy approach. Journal of Cleaner Production, 96, 182-193.

Gunasekaran, A. (1998). Agile manufacturing: enablers and an implementation framework. International Journal of Production Research, 36(5), 1223-1247.

Gunasekaran, A. (1999). Agile manufacturing: a framework for research and development. International Journal of Production Economics, 62(1-2), 87-105.

Hajmohammad, S., Vachon, S., Klassen, R. D., \& Gavronski, I. (2013). Reprint of Lean management and supply management: their role in green practices and performance. Journal of Cleaner Production, 56, 86-93.

Hines, P., Holweg, M., \& Rich, N. (2004). Learning to evolve: a review of contemporary lean thinking. International Journal of Operations \& Production Management, 24(10), 994-1011.

Hines, P., \& Rich, N. (1997). The seven value stream mapping tools. International Journal of Operations \& Production Management, 17(1), 46-64.

Jawahir, I., Dillon, O., Rouch, K., Joshi, K. J., Venkatachalam, A., \& Jaafar, I. H. (2006). Total life-cycle considerations in product design for sustainability: A framework for comprehensive evaluation. Paper presented at the Proceedings of the 10th International Research/Expert Conference, Barcelona, Spain.

Jeyaraman, K., \& Kee Teo, L. (2010). A conceptual framework for critical success factors of lean Six Sigma: Implementation on the performance of electronic manufacturing service industry. International Journal of Lean Six Sigma, 1(3), 191-215.

Ketokivi, M. A., \& Schroeder, R. G. (2004). Perceptual measures of performance: fact or fiction? Journal of operations management, 22(3), 247-264. 
INTERNATIONAL JOURNAL OF ACADEMIC RESEARCH IN BUSINESS AND SOCIAL SCIENCES

Vol. 8, No. 7, July 2018, E-ISSN: 2222-6990 @ 2018 HRMARS

Khanchanapong, T., Prajogo, D., Sohal, A. S., Cooper, B. K., Yeung, A. C., \& Cheng, T. (2014). The unique and complementary effects of manufacturing technologies and lean practices on manufacturing operational performance. International Journal of Production Economics, 153, 191-203.

Kidd, P. T. (1996). Agile manufacturing: a strategy for the 21st century.

Kurdve, M., Zackrisson, M., Wiktorsson, M., \& Harlin, U. (2014). Lean and green integration into production system models-experiences from Swedish industry. Journal of Cleaner Production, 85, 180-190.

Larson, T., \& Greenwood, R. (2004). Perfect complements: synergies between lean production and eco-sustainability initiatives. Environmental Quality Management, 13(4), 27-36.

Liker, J. K. (2004). The Toyota Way: 14 management principles from the World's greatest automaker: New York: McGraw-Hill.

Maxwell, D., Sheate, W., \& van der Vorst, R. (2006). Functional and systems aspects of the sustainable product and service development approach for industry. Journal of Cleaner Production, 14(17), 1466-1479.

Mollenkopf, D., Stolze, H., Tate, W. L., \& Ueltschy, M. (2010). Green, lean, and global supply chains. International Journal of Physical Distribution \& Logistics Management, 40(1/2), 14-41.

Narasimhan, R., Swink, M., \& Kim, S. W. (2006). Disentangling leanness and agility: an empirical investigation. Journal of operations management, 24(5), 440-457.

Pampanelli, A. B., Found, P., \& Bernardes, A. M. (2014). A Lean \& Green Model for a production cell. Journal of Cleaner Production, 85, 19-30.

Pavnaskar, S., Gershenson, J., \& Jambekar, A. (2003). Classification scheme for lean manufacturing tools. International Journal of Production Research, 41(13), 3075-3090.

Rothenberg, S., Pil, F. K., \& Maxwell, J. (2001). Lean, green, and the quest for superior environmental performance. Production and operations management, 10(3), 228-243.

Roy, M., \& Khastagir, D. (2016). Exploring role of green management in enhancing organizational efficiency in petro-chemical industry in India. Journal of Cleaner Production, 121, 109-115.

Sarkis, J. (2001). Manufacturing's role in corporate environmental sustainability-Concerns for the new millennium. International Journal of Operations \& Production Management, 21(5/6), 666-686.

Shah, R., \& Ward, P. T. (2003). Lean manufacturing: context, practice bundles, and performance. Journal of operations management, 21(2), 129-149.

Sharifi, H., \& Zhang, Z. (1999). A methodology for achieving agility in manufacturing organisations: An introduction. International Journal of Production Economics, 62(1-2), 7-22.

Sharp, J., Irani, Z., \& Desai, S. (1999). Working towards agile manufacturing in the UK industry. International Journal of Production Economics, 62(1-2), 155-169.

Sherehiy, B., Karwowski, W., \& Layer, J. K. (2007). A review of enterprise agility: Concepts, frameworks, and attributes. International Journal of industrial ergonomics, 37(5), 445-460.

Sobral, M. C., Sousa Jabbour, A. B. L. d., \& Chiappetta Jabbour, C. J. (2013). Green benefits from adopting lean manufacturing: a case study from the automotive sector. Environmental Quality Management, 22(3), 65-72.

Teece, D. J. (1986). Firm Boundaries, Technological Innovation And Strategic Planneng. En Lg Thomas.

Teixeira, A. A., Jabbour, C. J. C., \& de Sousa Jabbour, A. B. L. (2012). Relationship between green management and environmental training in companies located in Brazil: A theoretical framework and case studies. International Journal of Production Economics, 140(1), 318-329. 
INTERNATIONAL JOURNAL OF ACADEMIC RESEARCH IN BUSINESS AND SOCIAL SCIENCES

Vol. 8, No. 7, July 2018, E-ISSN: 2222-6990 @ 2018 HRMARS

Ulrich, D., Brockbank, W., Yeung, A. K., \& Lake, D. G. (1995). Human resource competencies: An empirical assessment. Human resource management, 34(4), 473-495.

Unnikrishnan, S., \& Hegde, D. (2007). Environmental training and cleaner production in Indian industry-A micro-level study. Resources, Conservation and Recycling, 50(4), 427-441.

Vazquez-Bustelo, D., Avella, L., \& Fernández, E. (2007). Agility drivers, enablers and outcomes: empirical test of an integrated agile manufacturing model. International Journal of Operations \& Production Management, 27(12), 1303-1332.

Wernerfelt, B. (1984). A resource-based view of the firm. Strategic management journal, 5(2), 171180.

Womack, J. P., Jones, D. T., \& Roos, D. (1990). Machine that changed the world. Simon and Schuster.

Woo, C., Kim, M. G., Chung, Y., \& Rho, J. J. (2016). Suppliers' communication capability and external green integration for green and financial performance in Korean construction industry. Journal of Cleaner Production, 112, 483-493.

Yang, M. G. M., Hong, P., \& Modi, S. B. (2011). Impact of lean manufacturing and environmental management on business performance: An empirical study of manufacturing firms. International Journal of Production Economics, 129(2), 251-261.

Zhan, Y., Tan, K. H., Ji, G., Chung, L., \& Chiu, A. S. (2018). Green and lean sustainable development path in China: Guanxi, practices and performance. Resources, Conservation and Recycling, 128, 240-249.

Zhang, L., Luo, Y., Tao, F., Li, B., Ren, L., Zhang, X., et al. (2014). Cloud manufacturing: a new manufacturing paradigm. Enterp Inf Syst 8 (2): 167-187.

Zhu, Q., Sarkis, J., \& Lai, K.-h. (2013). Institutional-based antecedents and performance outcomes of internal and external green supply chain management practices. Journal of Purchasing and Supply Management, 19(2), 106-117. 